\title{
Effect of organic, inorganic fertilizers and their combi- nation on vegetative growth and production of common bush beans RWR2245 variety in Rwanda
}

\author{
Rukundo Jean D'amour ${ }^{1 *}$, Mukamuhirwa Floride ${ }^{2}$, Nsigaye Alfred ${ }^{3}$ \\ ${ }^{1}$ Seed Science and Technology, Bogor Agriculture University, Jln. Meranti Kampus IPB Darmaga, Bogor, Indonesia \\ ${ }^{2}$ Rwanda Agriculture and Animal Resources Development Board, Huye, Rwanda \\ ${ }^{3}$ Post-harvest Management and Nutrition, Rwanda Agriculture Board, Huye, Rwanda
}

\section{Keywords \\ Bush bean \\ Organic \\ Inorganic \\ Fertilizers \\ Production}

Received: 6 October 2019

Accepted: 27 December 2019

Published: 12 February 2020

\begin{abstract}
The improvement of agriculture productivity is depending on many factors including high-quality seeds and fertilizers. Soil fertility and water holding capacity may affect plant growth which decreases production. This research aims to provide information on three different fertilizers used in the agriculture production system such as Yard Manure (Organic), Urea, DAP, and their combination on vegetative growth and productivity of bush beans RWR2245. Fertilizers were applied in each plot equally through Randomised Complete Block Design (RCBD). The plot without fertilizer had shown the highest germination percentage (T0) of 88.5\%, while the plot T5(Urea + FYM) had shown the lowest germination percentage of $43.5 \%$. Plant vigor parameters were evaluated at 20,30, and 40 days after sowing. T4(FYD + DAP) showed the highest growth rate and T0 (without fertilizer) had the lowest growth rate. By considering the diameter, T4 $(4.875 \mathrm{~mm})$ had the highest stem diameter, whereas T0 $(3.025 \mathrm{~mm})$ had a lower stem diameter. The maximum number of leaves obtained in T4 was 18.00, while the minimum number was 11.75 observed in treatment without fertilizer To (control). The productivity parameters such as the day at $50 \%$ flowering after planting, the plant pod number, seeds number in pod per plant, the weight of 1000 bean grains for each treatment, and the total yield in tons per hectare $(t / H a)$ were observed, and results show that the combination of T4 (FYM + DAP) and T1 (FYM+UREA) applied alone resulted in the highest yield (2.41t/ha) and $2.06 \mathrm{t} / \mathrm{ha}$ in average, respectively, while the treatment without fertilizer T0 showed the lowest result of 1.7t/ha. Different fertilizer levels had a significant effect $(p<0.05)$ on $50 \%$ flowering.
\end{abstract}

(C) 2020 The Author(s). Published by TAF Publishing.

\section{INTRODUCTION}

Common bean, Phaseolus vulgaris L., is mostly considered as a seasonal food crop that is used as a source of protein for the human being. According to [1], bean crops dispersed in the world from America until planted in many countries based on their socio-economic value to the society. Beans production is affected by main factors includes the cost of inputs investment, competition with crops, and cropping systems used by the farmers [2]. Bean productivity is affected (pocked) by different factors which include the supply of the appropriate fertilizers necessary to crops. [3] reported that the fertilizer types, rates, and application time is very essential as it has an impact on both vegetative and reproductive growth of the crops based nutrients at any stages which resulted on increasing or decreasing production.

Fertilizer nutrients can be classified into two kinds based on requirements by crops those are macro and micronutrients. According to [4] the bean production and most of the legume vegetables in the tropic are depending on the types of fertilizers used by the farmers. Agriculture production must be associated with the use of fertilizer for increasing production in terms of quality and quantity. The use of synthetic fertilizer has shown a higher contribution

\footnotetext{
${ }^{*}$ Corresponding author: Rukundo Jean D’amour

†email: rukundojeandamou06@gmail.com
} 
for crop production but different research also has shown many benefits of using organic fertilizer as a contribution for soil improvement soil, with no effect on the users and environment [5, 6]. According to [7], it is very necessary to suggest new sources of organic fertilizer and improve the existing sources such that animal wastes, waste from plants, decomposable home waste, and green manures. The organic fertilizers provide the necessary chemical elements and some of the microorganisms which contribute to soil structure and fertility improvement that resulted in gas and water maintenance by the soil [8]. The plant roots part grows well depending on the soil structure and texture however that has an impact on the plant shoot part.

Inorganic fertilizers are used by most vegetable and legumes producers because inorganic fertilizer provides the exact nutrient needed by the plant especially macronutrients that lead to yield improvement $[9,10]$. Most of the farmer doesn't consider the impact of inorganic fertilizer for the soil and future production. [9] reported that the use of no synthetic fertilizers such as compost, plant residue, farmyard manure, or green mature may reduce the cost of production and maintain food quality without fertilizer residue. Different research has been done and resulted in many benefits of using organic fertilizer like [11]. Shown the effect of using no synthetic fertilizer on soil, plant, and soil microorganism. All can contribute to increasing agriculture production. General, there is a gap of information related to the use of both fertilizers as research has shown different advantages and disadvantages for each type of fertilizer but both have an impact on improving production. This research aims to evaluate the effect of organic-inorganic fertilizer and their combination on vegetative growth and production of bush bean Rw2245 variety.

\section{RESEARCH METHODS AND MATERIALS}

This research was conducted at Rwanda Agriculture Board (RAB) in the southern province of Rwanda during the rainy season of the year 2014 .

\section{A. Experimental Site}

RAB is about 1650 meters above sea level and is located in Huye district- Southern province. the average temperature of this site is about $19 \mathrm{oC}$ and the average rainfall ranged between $1400-1600 \mathrm{~mm}$ with soil acidity 5.5 to $5.8 \mathrm{pH}$. This site exhibits a tropical extreme climate with the dry season and rainy season. This research will be conducted during the rainy season which is expected to start from January to May. During this research, the main materials to be used are bush bean plants (Phaseolus vulgaris (L.) RWR2245 variety and farmyard manure were obtained from Rwanda Agriculture Board while fertilizers (DAP and UREA) were obtained from Agrotech (Agriculture Technology. Ltd). The fertilizer to be applied in each plot was calculated according to the quantity needed per hectare. The data will be collected based on vegetative and reproductive parameters which include germination percentage, plant diameter, the height of the plant, total leaves per plant, flowering rate, total pods per plant, seeds per pod, production per plot, and weight of 1000 bean grain to determine biomass. Complete Randomized Block Design (CRBD) was used with 6 treatments and each will be replicated 4 times means 24 experiment units. The experiment was conducted from February 2014 to May 2015 and the data will be collected on the 10th, 20th, 40th days. TABLE 1

\begin{tabular}{lll}
\multicolumn{2}{l}{ FIELD DESIGN AND REQUIRED FERTILIZER INPUT } \\
\hline \hline Treatment & Material & Quantity \\
\hline To & WITHOUT FERTILISER & 0 \\
T1 & FYM & $12 \mathrm{Kg}$ \\
T2 & DAP & $140 \mathrm{~g}$ \\
T3 & UREA & $720 \mathrm{~g}$ \\
T4 & DAP+FYM & $140 \mathrm{~g}+12 \mathrm{~kg}$ \\
T5 & UREA+FYM & $720 \mathrm{~g}+12 \mathrm{~kg}$ \\
\hline \hline
\end{tabular}

FYM: Farm Yard Manure; DAP: Diammonium phosphate

\section{B. Statistical analysis}

The collected data were analyzed by using Microsoft Excel and ANOVA.

\section{RESULT AND DISCUSSION}

\section{A. Germination}

The highest germination percentage has been recorded in the plot without fertilizer (T0) with (88.5\%), followed by T1 (FYM) with a germination percentage of $86.5 \%$ while the lowest germination percentage has been recorded in $\mathrm{T} 5$ (Urea + FYM) with $43.5 \%$. The results were significantly different between treatments at a $5 \%$ level of significance. The result obtained can be categorized into three homogeneous groups as the treatments with the same letter are not significantly different. The result is similar and approved by resulted research of [12] shown that seed germination is affected by both organic and inorganic fertilizer in terms of nutrients content. so that fertilizers are requested by the plant after roots emergency for being used as source nutrient for vegetative growth. 
TABLE 2

THE EFFECT OF ORGANIC, INORGANIC FERTILIZERS AND THEIR COMBINATIONS ON PLANT GERMINATION PERCENTAGE AFTER 8 DAYS

\begin{tabular}{llll}
\hline \hline Treatment & Germination Rate & HG & \\
\hline T0 & 88.5 & A & \\
T1 & 86.5 & A & \\
T2 & 63.75 & B & \\
T3 & 56.25 & Bc & \\
T4 & 65.5 & B & \\
T5 & 43.5 & C & \\
Grand mean & 67.3 & & \\
L.S.D & 16.01 & CV\% & 2.6 \\
\hline \hline
\end{tabular}

\section{B. Height of bean plant}

Figure 1 represents the result recorded about plant height at 20th, 30th, and 40th days after sowing (DAS). The best performance has been recorded in the treatment(T4) as a combination of DAP and FYM with an average of $34.32 \mathrm{~cm}$, whereas To(control without fertilizer) has resulted to slow growth with $20 \mathrm{~cm}$ height. The plant height is depending on the fertilizer used as the nutrient deficiency can leads to crop stunting. Normally, DAP provides both phosphorus and nitrogen as nutrient whose function impact positively on crops growth. As reported by [13]. Nitrogen has a function to stimulate the growth and to increase the protein content of crops grown as well as regulating the use of phosphorus, potassium, and other nutrients. [14] reported that soil nutrients play a crucial role in plant growth. Furthermore, applying mineral fertilizer and FYM increases the soil nutrients availability and enhances microbial activity, which influences plant growth and yield in general. [15] reported that plants which received nitrogen and phosphorus nutrient from fertilizer growth faster and that contribute to plant elongation.

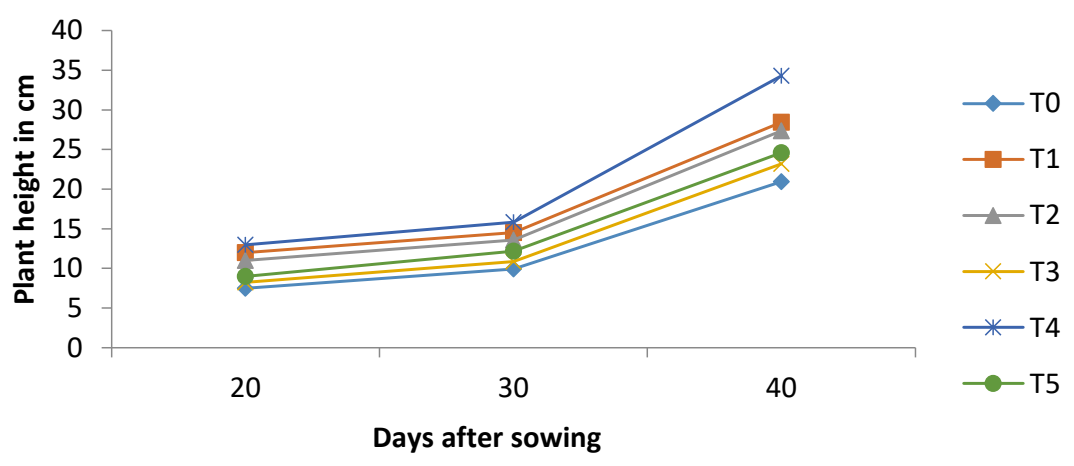

Fig. 1. The effect of organic, inorganic fertilizers and their combinations on the plant on crop height at 10,20 , and 40 days after planting

\section{Number of leaves}

The number of leaves was recorded on the 20th, 30th, and 40th days; Figure 3 presents the number of leaves at 10 days intervals, where the maximum number of leaves were observed in T4 (3.75), while the minimum ones were observed in T5(3) and T3(3) at 20th day. The results after the 40th day showed the maximum mean number of leaves in T4 (18.00), while the minimum was observed in T0 (11.75). [16] reported that plant length and the number of leaves increased with the application of DAP fertilizer until optimum and organic fertilizer contributes to soil water holding capacity. This proves the presence of many leaves number in combination with DAP and FYM treatment.

Time-evolution of number of leaves

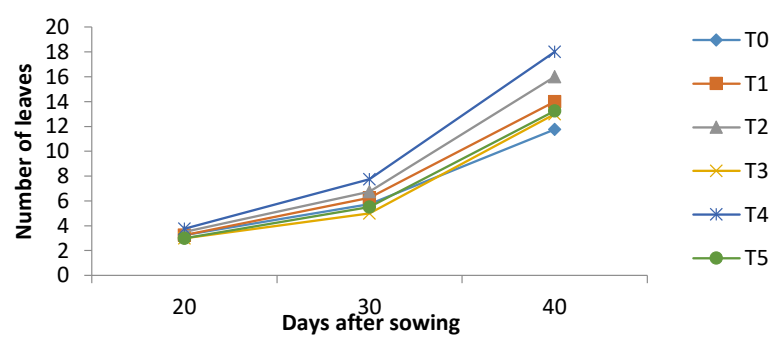

Fig. 2. The effect of organic, inorganic fertilizers and their combinations on plant leaves shading after 10, 20, and 40 days of planting stem diameter 
In general stem, diameter increased from the 20th day to the 40th day after sowing. The levels of FYM, DAP, and Urea were measured on the 20th, 30th, and 40th days after sowing. The means resulted of stem diameter 40th days after sowing demonstrated that the maximum stem diameter was observed in $\mathrm{T} 4(4.875 \mathrm{~mm})$, while the minimum was in T0 $(3.025 \mathrm{~mm})$. [16] showed that two macronutrients ( $\mathrm{N}$ and $\mathrm{P}$ ) that plants obtained from Diammonium Phosphate have a higher contribution to plants' food synthesis and plant cell multiplication. The plant absorbed nutrients in form of ions that shown the contribution of FYM for improving soil water holding capacity. Therefore, a combination of both DAP and FYM has shown a greater contribution to plant vigor regarding plant diameter.

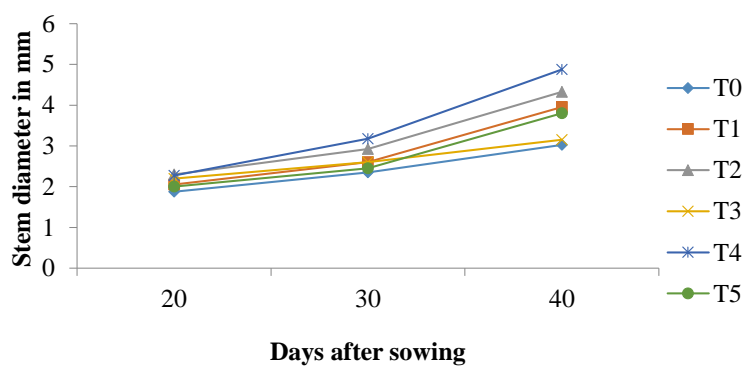

Fig. 3. the effect of organic, inorganic fertilizers and their combinations on stem diameter at 20th, 30th, and 40th Days After Sowing (DAS)

\section{Days to $50 \%$ flowering}

Data related to flowering was collected when $50 \%$ of plants had flowers. During this study, it was observed that the bean started to flower at different dates varied from 40.5 to 43.25 days to obtain $50 \%$ flowering. The earlier flowering was recorded in T3 followed by T2, while T5 was had late flowering. This allows classifying the results into 3 homogenous groups mentioned from the Table above such as $\mathrm{a}, \mathrm{ab}$ and $\mathrm{b}$. Different fertilizer levels had a highly significant $(p<0.05)$ effect on days taken to flowering. The Maximum (43.25) days taken to flowering were recorded in T5 (Urea + FYM), followed by T4 (43.15) DAP + FYM, T0 (41.5) days, $\mathrm{T} 1$ (41.25) days, and T2 (41) days. The minimum (40.5) results for days taken to flowering were recorded in T3 corresponded to plots with bush beans that had early flowering (Table 3). The deficiency of major nutrients stunted the plant growth resulting in maximum days taken to flowering. Gradual increase in fertilizer levels reduced the days taken to flowering up to a certain limit and vice versa. [17] reported that the combination of DAP and FYM is very ef- fective for stimulating and maximum flowering in Chile. TABLE 3

THE EFFECT OF ORGANIC, INORGANIC FERTILIZERS AND THEIR COMBINATION ON PLANT FLOWERING

\begin{tabular}{llll}
\hline \hline Treatment & Day to 50\% flowering & HG & \\
\hline T0 & 41.5 & b & \\
T1 & 41.25 & b & \\
T2 & 41 & b & \\
T3 & 40.5 & b & \\
T4 & 43.15 & ab & \\
T5 & 43.25 & a & \\
Grand mean & 40.96 & & \\
l.s.d & 2.516 & CV\% & 0.685 \\
\hline \hline
\end{tabular}

Mean values followed by the same letter in the same column do not differ significantly at a 5\% level of significance

\section{E. Fertilizers and yield parameters}

According to the results obtained on the effect of fertilizer on yield parameter, the high number of pods per plant has been recorded in T4 (25.81) while the lowest was recorded in T0(14.19). The result about the number of pods per plant has shown no differ significantly among treatment $\mathrm{T} 0, \mathrm{~T} 1$, $\mathrm{T} 2$, and $\mathrm{T} 3$ but significantly different to T4 and T5. This result is justified by [18] reported bean production is depending on the types, amount, and time of fertilizer application. The production differs among the treatment according to the types of fertilizer used (FYM and DAP, and Urea) as presented in Table 4 indicated that both fertilizer application, as well as their combination, has no significant effect $(p>$ 0.05 ) on the number of grains per pod. Similar results have been reported by [19] on pod yield with fertilizer and manure application. This data analysis indicated that both fertilizer application, as well as their combination, has no significant effect on the number of grains per pod. Statistical analysis of data presented in Table 4 indicates that FYM application with DAP had a highly significant $(p<.001)$ effect on 1000 grains weight. However, the maximum 1000 grain weights (241 g) were recorded from the plot that received DAP + FYM (T4), while the minimum 1000 grains weights (170 g) were noted from the control plots (T0) with no fertilizers. Some research reported that like [15], they have shown that the pod dry biomass and pod biomass, as well as total shoots and roots(number and elongation) depending on fertilizer nutrients content. [20] and [21] also reported that the combination of organic and inorganic fertilizer in treatments has a positive impact on pod dry weight of the legumes comparing to those received uncombined fertilizer. 
TABLE 4

THE EFFECT OF ORGANIC, INORGANIC FERTILIZER AND THEIR COMBINATION ON THE NUMBER OF PODS PER PLANT, NUMBER OF SEEDS PER POD, AND WEIGHT OF 1000 GRAIN

\begin{tabular}{lllllll}
\hline \hline Treatment & Numb of Pods/Plant & HG & Numb of Grains in P/Plant & HG & Weight of 1000 grain/plot & HG \\
\hline T0 & 14.19 & $\mathrm{c}$ & 5.525 & $\mathrm{~A}$ & 170 & $\mathrm{~d}$ \\
T1 & 20.12 & $\mathrm{bc}$ & 6.055 & $\mathrm{~A}$ & 206 & $\mathrm{bc}$ \\
T2 & 19.62 & $\mathrm{c}$ & 6 & $\mathrm{~A}$ & 198 & $\mathrm{c}$ \\
T3 & 18.88 & $\mathrm{c}$ & 5.812 & $\mathrm{~A}$ & 189 & $\mathrm{c}$ \\
T4 & 25.81 & $\mathrm{a}$ & 6.25 & $\mathrm{~A}$ & 241 & $\mathrm{a}$ \\
T5 & 21.57 & $\mathrm{ab}$ & 5.877 & $\mathrm{~A}$ & 217 & $\mathrm{ab}$ \\
Grand mean & 19.53 & 6.02 & 203.5 & & & \\
l.s.d & 6.214 & 0.6323 & 19.29 & & & \\
CV\% & 9.1 & 2.6 & 2.1 & & & \\
\hline \hline
\end{tabular}

Mean values followed by the same letter in the same column do not differ significantly at a 5\% level of significance, as referred to as the least significant difference (L.S.D test).

\section{F. Bean yield in $\mathrm{t} / \mathrm{ha}$}

The increase in the number of mature pods per plant and pod weight per plant resulted from the use of combined fertilizer during agriculture production [22]. This justifies the best yield obtained in the treatments T4 (2.41tones) and T5 (2.17tones), which received the combination of DAP + FYM and UREA + FYM. The lowest yield was recorded in Control plot T0 (1.7tones) and that is similar to [22] finds where the application of FYM in their combinations with inorganic fertilizer has produced a higher number of mature pods per plant, pod weight per plant, number of kernels per pod, pod weight, pod yield, and haulm yield of groundnut comparing to the use of fertilizer individually fertilizers.

TABLE 5

THE EFFECT OF ORGANIC, INORGANIC FERTILIZER AND THEIR COMBINATION ON BEAN YIELD (T/HA)

\begin{tabular}{|c|c|c|c|}
\hline Treatment & The Yield of Bean in t/ha Per Plot & HG & \\
\hline T0 & 1.7 & $\mathrm{D}$ & \\
\hline $\mathrm{T} 1$ & 2.06 & $\mathrm{Bc}$ & \\
\hline $\mathrm{T} 2$ & 1.98 & $\mathrm{Bc}$ & \\
\hline T3 & 1.89 & $\mathrm{C}$ & \\
\hline $\mathrm{T} 4$ & 2.41 & A & \\
\hline $\mathrm{T} 5$ & 2.17 & $\mathrm{Ab}$ & \\
\hline Grand mean & 2.035 & & \\
\hline l.s.d & 0.192 & $\mathrm{CV} \%$ & 2.1 \\
\hline
\end{tabular}

Mean values followed by the same letter do not differ significantly at the $5 \%$ level of significance, as referred to as the least significance difference (L.S.D) test.

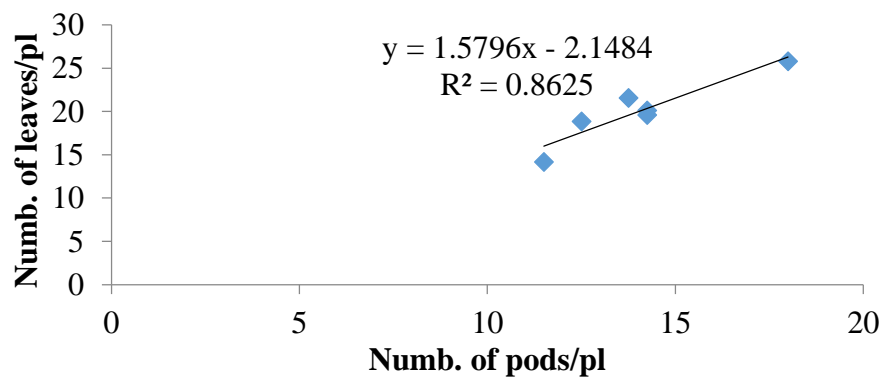

Fig. 4. Colerraction between the number of leaves and number of pods

The results from Figure 4 show that there is a positive correlation between the number of leaves and the number of pods indicating that increasing the number of pods increased the number of leaves at a correlation coefficient of $(r=0.928)$. The results depicted in Figure 5 showed a strong positive correlation between the number of pods and yield (the yield) of the bean per hectare $(r=0.984$ or $98.4 \%$ ), thus, this means that more is the plant pods, more is the productivity per hectare. 


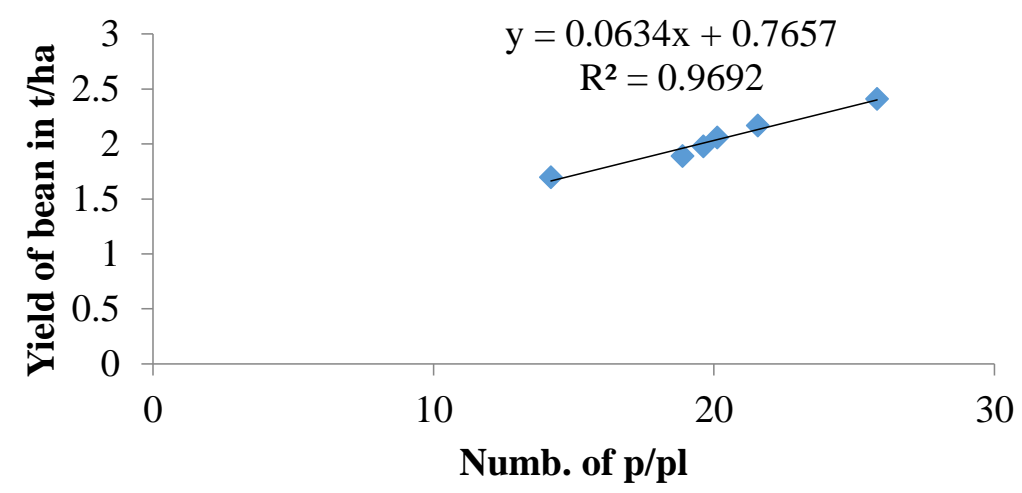

Fig. 5. Reasons for joining solidary agriculture

\section{CONCLUSION}

In the present study, the three types of fertilizer used (organic, inorganic, and their combination) showed better performance-based plant height, flowering, pod number, number of pod per pod, seed weight, and crop yield. By evaluating those variables, the combination of organic and inorganic fertilizer has shown the highest effect on improving productivity. Both (DAP + FYM) and (UREA + FYM) can give $2.41 \mathrm{t} / \mathrm{ha}$ and $2.17 \mathrm{t} / \mathrm{ha}$ yield of grains on average respectively especially for the bean crop RWR2245 variety. However, we are encouraged the farmer to use the combination of organic and inorganic fertilizers for improving productiv- ity. On another side, we encourage the researchers to continue this study by using mineral (DAP and Urea) and organic (FYM) fertilizers to evaluate their effect on nodulation of common beans for improving the soil conditions and can reduce the cost for fertilizer input.

\section{A. Financial support and acknowledgment}

The author sincerely convey particular thanks to the University of Rwanda-College of Agriculture and Veterinary Medicine administration (UR-CAVM) and Rwanda Agriculture Board (RAB) for providing professional support and guidance during this research work.

\section{REFERENCES}

[1] M. A. Islam, A. N. Boyce, M. M. Rahman, M. S. Azirun, and M. A. Ashraf, "Effects of organic fertilizers on the growth and yield of bush bean, winged bean and yard long bean," Brazilian Archives of Biology and Technology, vol. 59, pp. 1-9, 2016. doi: https://doi.org/10.1590/1678-4324-2016160586

[2] A. Pinchinat, J. Soria, and R. Bazan, "Multiple cropping in tropical America," Multiple Cropping, vol. 27, pp. 51-61, 1976.

[3] I. Dimitrov, I. Stancheva, I. Mitova, and E. Atanasova, "Quality and yield of lettuce in dependence of different fertilizer sources," Bulgarian Journal of Agricultural Science (Bulgaria), vol. 5, pp. 589-594, 2005.

[4] K. Takahashi, "Physiological disorders in Chinese cabbage," Shanhua, Taiwan: AVRDC, Tech. Rep., 1981.

[5] P. Mäder, A. Fliessbach, D. Dubois, L. Gunst, P. Fried, and U. Niggli, "Soil fertility and biodiversity in organic farming," Science, vol. 296, pp. 1694-1697, 2002. doi: https://doi.org/10.1126/science.1071148

[6] C. Francis and H. Daniel, "Organic farming. encyclopedia of soils in the environment," 2004.

[7] D. Shannon, A. Sen, and D. Johnson, "A comparative study of the microbiology of soils managed under organic and conventional regimes," Soil Use and Management, vol. 18, pp. 274-283, 2002. doi: https://doi.org/10.1111/j.1475-2743. 2002.tb00269.x

[8] M. Pagliai, N. Vignozzi, and S. Pellegrini, "Soil structure and the effect of management practices," Soil and Tillage Research, vol. 79, no. 2, pp. 131-143, 2004. doi: https://doi.org/10.1016/j.still.2004.07.002

[9] S. Thy and P. Buntha, "Evaluation of fertilizer of fresh solid manure, composted manure or biodigester effluent for growing Chinese cabbage (Brassica pekinensis)," Livestock Research for Rural Development, vol. 17, no. 3, pp. 149-154, 2005.

[10] R. Prihandarini and Sudiarso, "Utilization of oil mimba and organic fertilizer of paitan leaves based on microorganism for improving growth and sweet corn (zea mays var. saccharata sturt) production," International Journal of Applied and Physical Sciences, vol. 4, no. 1, pp. 29-37, 2018. doi: https://dx.doi.org/10.20469/ijaps.4.50005-1 
[11] R. Albiach, R. Canet, F. Pomares, and F. Ingelmo, "Microbial biomass content and enzymatic activities after the application of organic amendments to a horticultural soil," Bioresource Technology, vol. 75, no. 1, pp. 43-48, 2000. doi: https://doi.org/10.1016/S0960-8524(00)00030-4

[12] A. Ramteke, M. Narwade, A. Gurav, S. Chavan, A. Wandre et al., "Study of germination effect of fertilizers like urea NPK and biozyme on some vegetable plants," Der Chemica Sinica, vol. 4, no. 3, pp. 22-26, 2013.

[13] G. Soepardi, "Soil properties and characteristics," Unpublished dissertation, Faculty of Agriculture, Institut Pertanian Bogor, Bogor, Indonesia, 1983.

[14] R. L. Donahue, R. W. Miller, J. C. Shickluna et al., Soils. An introduction to soils and plant growth. Hoboken, NJ: PrenticeHall, Inc., 1983.

[15] M. Valdez-Perez, F. Fernandez-Luqueno, O. Franco-Hernandez, L. F. Cotera, and L. Dendooven, "Cultivation of beans (Phaseolus vulgaris L.) in limed or unlimed wastewater sludge, vermicompost or inorganic amended soil," Scientia Horticulturae, vol. 128, no. 4, pp. 380-387, 2011.

[16] M. Azeem, R. Hayat, Q. Hussain, M. I. Tahir, M. Imran, Z. Abbas, M. Sajid, A. Latif, and M. Irfan, “Effects of biochar and NPK on soil microbial biomass and enzyme activity during 2 years of application in the arid region," Arabian Journal of Geosciences, vol. 12, no. 10, pp. 1-13, 2019. doi: https://doi.org/10.1007/s12517-019-4482-1

[17] N. Naeem, I. Muhammad, J. Khan, G. Nabi, N. Muhammad, and N. Badshah, “Influence of various levels of nitrogen and phosphorus on growth and yield of chilli (Capsicum annum l.)," Asian Journal of Plant Sciences, vol. 1, no. 5, pp. 599-601, 2002.

[18] N. I. Singh and J. Chauhan, "Response of French bean (Phaseolus vulgaris L.) to organic manures and inorganic fertilizer on growth and yield parameters under irrigated condition," Nature and Science, vol. 7, no. 5, pp. 52-54, 2009.

[19] A. Basir, Z. Shah, M. Naeem, J. Bakht, and Z. Khan, "Effect of phosphorus and farm yard manure on agronomic traits of chickpea (Cicer arietinum L.)," Sarhad Journal of Agriculture, vol. 24, no. 4, pp. 567-572, 2008.

[20] C. A. Edwards, "Historical overview of vermicomposting," Biocycle, vol. 36, no. 6, pp. 56-58, 1995.

[21] B. Lalljee, "Effects of two commercially available composts on soil properties, and yield and mineral content of bean (Phaseolus vulgaris)," Revue Agricole et Sucriere de l'Ile Maurice, vol. 85, pp. 75-83, 2006.

[22] S. Kumaran, "Response of groundnut to organic manure, fertilizer levels, split application of phosphorus and gypsum application under irrigated condition," Research on Crops, vol. 2, no. 2, pp. 156-158, 2001. 